\title{
Użyteczność i ograniczenia badania 18F-FDG PET/CT w diagnostyce nowotworu złośliwego przełyku
}

\section{The utility and limitations of the 18F-FDG PET/CT study in the oesophageal neoplasms diagnosis}

\author{
Agata Karolina Pietrzak ${ }^{1}$, Piotr Martenka², Erwin Strzesak ${ }^{3}$, \\ Katarzyna Pietrasz ${ }^{1}$, Aleksandra Heydrych ${ }^{1}$, Beata Pisarska ${ }^{1}$, \\ Karolina Kucnerowicz ${ }^{3}$, Witold Cholewiński ${ }^{1}$ \\ ${ }^{1}$ Zakład Medycyny Nuklearnej, Wielkopolskie Centrum Onkologii, Poznań, Polska \\ ${ }^{2} Z a k ł a d$ Radioterapi, Wielkopolskie Centrum Onkologii, Poznań, Polska \\ 3Dziat Ewidencji Świadczeń Medycznych Wielkopolskiego Centrum Onkologii, Poznań, Polska
}

\begin{abstract}
Wstęp
Nowotwór złośliwy przełyku (ang. oesophageal cancer - OC, esophageal cancer - EC) jest jednym z najczęstszych rozpoznań i szóstą przyczyną zgonów z przyczyn onkologicznych na świecie [1]. Istotną rolą wdiagnostyce obrazowej OCzajmują: ultrasonografia endoskopowa(ang.endoscopicultrasonography-EUS), tomografia komputerowa ze wzmocnieniem kontrastowym (ang. contrast-enhanced computed tomography - ${ }_{\text {ce }} \mathrm{CT}$ ), a także pozytonowa tomografia emisyjna/tomografia komputerowa z użyciem radiofarmaceutyku ${ }^{18}$ F-Fluorodeoksyglukozy (ang. 2-deoxy-2-[18F]fluoro-D-glucose positron emission tomography/computed tomography, ${ }^{18} \mathrm{~F}-\mathrm{FDG}$ PET/CT) [2,3]. Zdaniem autorów [3,4-6], badania ${ }_{\text {ce }} \mathrm{CT}$ i ${ }^{18} \mathrm{~F}-\mathrm{FDG}$ PET/CT są wysoce użyteczne w diagnostyce OC, jednakże technikę ${ }^{18} \mathrm{~F}$-FDG PET/CT cechuje wyższa czułość i swoistość w ocenie zaawansowania węzłowego i wykrywaniu przerzutów odległych. Obie metody łączy natomiast ograniczona zdolność do precyzyjnej oceny cechy T, czyli masy guza pierwotnego. Metodą z wyboru w ocenie T jest EUS, którego dostępność jest obecnie niewielka.
\end{abstract}

Terapia OC obejmuje leczenie chirurgiczne, chemioterapię, radioterapię lub terapię skojarzoną [7]. Wybór właściwego wariantu uzależniony jest od stopnia zaawansowania choroby, ocenianego według ósmej edycji klasyfikacji, z ang. Tumor-Node-Metastases (brak polskojęzycznego odpowiednika, w tłumaczeniu: guzwęzeł-przerzut, TNM). Precyzyjna ocena TNM, w szczególności: wykrycie przerzutów odległych, decyduje

Adres do korespondencji

Agata Karolina Pietrzak

Zakład Medycyny Nuklearnej,,

Wielkopolskie Centrum Onkologii, ul. Garbary 15, 61-866 Poznań, Polska

Telefon. +48 61 8850-789

e-mail: agata.pietrzakk@gmail.com 
o możliwości wdrożenia leczenia radykalnego. Z uwagi na rosnącą liczbę nowych zachorowań na OC [8], zarówno wśród mężczyzn, jak i kobiet, właściwe przyporządkowanie chorych onkologicznie do grupy leczonych radykalnie i paliatywnie, wydaje się być bardzo istotne.

\section{Cel pracy}

Celem niniejszej pracy jest wskazanie roli metody ${ }^{18} \mathrm{~F}-\mathrm{FDG}$ PET/CT w ocenie stopnia zaawansowania nowotworu złośliwego przełyku i procesieplanowania leczenia, zuwzględnieniem ograniczeń diagnostycznych metody.

\section{Material i metoda}

Niniejsza praca powstała w oparciu o analizę aktualnej literatury oraz własne doświadczenia w zakresie badań użyteczności ${ }^{18}$ F-FDG PET/CT w diagnostyce nowotworu złośliwego przełyku.

\section{Omówienie}

\section{- Diagnostyka różnych typów histologicznych OC}

Nowotwór złośliwy przełyku to przede wszystkim rak płaskonabłonkowy (ang. oesophageal squamous cell cancer - OSCC), obejmujący w przybliżeniu 90\% wszystkich przypadków OC. Rzadko występującą postacią histologiczną OC jest rak gruczołowy (ang. oesophageal adenocarcinoma - OAC), którego częstość występowania istotnie wzrosła w minionych latach, szczególnie w krajach Europy Północnej i Zachodniej, [8-10]. Najwyższy odsetek nowych zachorowań na świecie, zanotowano w Zjednoczonym Królestwie w roku 2012 (OAC) oraz w Azji Środkowej (OSCC) [10]. Mimo, że OAC uznawana jest za bardziej agresywną i gorzej rokującą postać OC, diagnostyka i terapia obu typów nowotworów odbywa się według podobnych schematów. W leczeniu zarówno OSCC, jak i OAC, istotną rolę odgrywa postępowanie radykalne skojarzone, obejmujące zabieg chirurgiczny (usunięcie ogniska pierwotnego i pojedynczych zmiany węzłowych) i radiochemioterapię (schematy obejmujące taksany, cisplatinę, 5-fluorouracyl i ich pochodne). Stąd, celem diagnostyki obrazowej jest ocena stopnia naciekania tkanek sąsiadujących przez ognisko pierwotne, wskazanie obecności przerzutów nowotworowych do węzłów chłonnych oraz zmian odległych. Stopniowanie OC według klasyfikacji TNM obejmuje ocenę T w zakresie 1-4 z podziałem na podtypy a i b. Cecha N ewaluowana jest według następującego schematu: 1 oznacza jeden lub dwa węzły chłonne objęte procesem chorobowym, 2 - trzy do sześciu, 3 siedem lub więcej węzłów chłonnych. Cecha $M$ obejmuje jedynie dwa warianty: o (brak stwierdzonych zmian przerzutowych) lub 1 (każda liczba ognisk odległych). Z punktu widzenia kwalifikacji do leczenia radykalnego, obecność przerzutu odległego uniemożliwia wdrożenie terapii radykalnej w każdym przypadku $[1,3]$. Rolą metody diagnostycznej jest zatem ocena zaawansowania węzłowego oraz wykluczenia innych zmian złośliwych. Badanie ${ }_{\text {ce }}$ CT obejmuje zwykle region klatki piersiowej (m.in. ocena zmian w płucach) i jamy brzusznej (m.in. poszukiwanie ognisk przerzutowych w miąższu wątroby). Standardowy protokół akwizycyjny ${ }^{18}$ F-FDG PET/CT obejmuje obszar od szczytu czaszki do połowy długości kości udowych, stąd ocena ww. regionów jest możliwa przy zastosowaniu każdej z metod.

\section{- Czułość, swoistość, dokładność metody ${ }^{18}$ F-FDG PET/CT w ocenie OC}

Czułość i swoistość metody ${ }^{18} \mathrm{~F}$-FDG PET/CT w ocenie przerzutów odległych w przebiegu OSCC wynosi odpowiednio 81\%, 91\% [11]. Zdaniem autorów [2,9,11-14], może być ponadto wykorzystywana w ocenie cechy N, szczególnie u chorych z rozpoznanym OAC (Tabela 1.). Ograniczeniem badania ${ }^{18}$ F-FDG PET/CT w diagnostyce przerzutów do węzłów chłonnych jest jednakże niska - w stosunku do wymiarów węzłów chłonnych - rozdzielczość przestrzenna. W przypadku wznowy raka przełyku, technikę PET/CT cechuje względnie wysoka, w porównaniu z dostępnymi metodami obrazowymi, czułość, specyficzność i dokładność na poziomie, odpowiednio, 94\%, 82\%, 87\% [11]. Badanie ${ }^{18} \mathrm{~F}-\mathrm{FDG}$ PET/CT pozwala na przedoperacyjną ocenę stopnia zaawansowania OSCC i OAC z czułością wahającą się w zakresie 67\%-74\% [13,14]. 
Tabela 1. Czułość, specyficzność i dokładność diagnostyczna metody ${ }^{18} \mathrm{~F}-\mathrm{FDG}$ PET/CT w ocenie zaawansowania węzłowego OSCC i OAC (źródło: [9, 14])

Porównanie parametrów dokładności diagnostycznej metody ${ }^{18}$ F-FDG PET/CT w diagnostyce OSCC, OAC

\begin{tabular}{|c|c|c|c|}
\hline $\begin{array}{c}\text { Typ } \\
\text { histologiczny/ } \\
\text { parametr }\end{array}$ & $\begin{array}{c}\text { czułość } \\
{[\%]}\end{array}$ & specyficzność [\%] & dokładność [\%] \\
\hline OSCC & 30,3 & 84,8 & 72,4 \\
\hline OAC & 39,2 & 83,3 & 55,0 \\
\hline
\end{tabular}

Istotnym ograniczeniem metody jest zdolność do precyzyjnej oceny cechy $\boldsymbol{T}$. Skanowanie metodą ${ }^{18}$ F-FDG PET/CT umożliwia natomiast wykrycie wzrostu aktywności metabolizmu glukozy w obszarze guza, co widoczne jest na przekrojach PET jako ogniska podwyższonej akumulacji radiofarmaceutyku. W przypadku badania cechy T, metoda ${ }^{18} \mathrm{~F}-\mathrm{FDG}$ PET/CT wykazuje szczególną przydatność w ocenie OSCC z uwagi na zwiększoną tendencję do wychwytu radioznacznika przez guzy płaskonabłonkowe w porównaniu z nowotworami pochodzenia gruczołowego (Rycina 1.) [2].

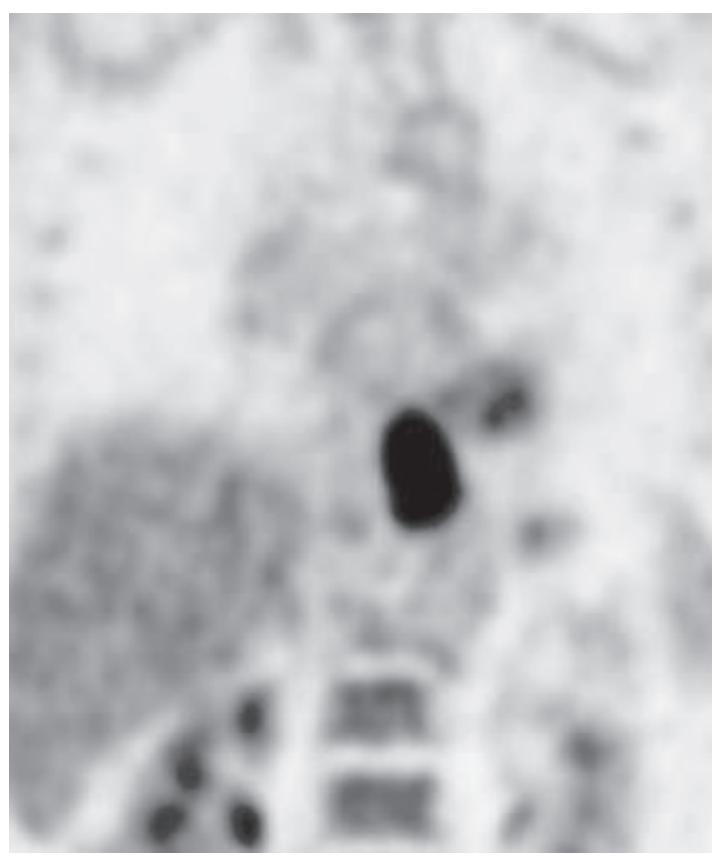

Rycina 1. Guz płaskonabłonkowy, widziany na przekroju czołowym ${ }^{18}$ F-FDG PET (źródło: rycina własna, Zakład Medycyny Nuklearnej WCO)

Powszechnie stosowane $\mathrm{w}$ diagnostyce OSCC i OAC metody obrazowe ${ }^{18} \mathrm{~F}-\mathrm{FDG}$ PET/CT i ${ }_{\text {ce }} \mathrm{CT}$, łączy ograniczona zdolność do oceny cechy T. Badanie PET/CT wykazuje wyższą niż ce CT czułość i swoistość w określeniu zarówno stopnia zaawansowania węzłowego nowotworu i obecności przerzutów odległych, jak i oceny efektywności leczenia [4,6,15]. Obie metody uznawane są jednak za niezwykle istotne w diagnostyce nowotworów złośliwych przełyku, bez względu na typ utkania histologicznego guza pierwotnego.

Ewaluacja stopnia zaawansowania OC jest szczególnie istotnym elementem planowania leczenia przeciwnowotworowego. Wdrożenie badania ${ }^{18} \mathrm{~F}-\mathrm{FDG}$ PET/CT w postępowanie diagnostyczne jest uznawane za przyczynę występowania zjawiska, znanego jako, z ang. stage migration, które w kontekście oceny z użyciem klasyfikacji TNM, oznacza zmianę stopniowania nowotworu, skutkującą modyfikacją planowanego 
postępowania leczniczego [4,15-17]. Zmiana ta polega zwykle na wyłączeniu osoby badanej z grupy chorych leczonych radykalnie z uwagi na obecność przerzutów odległych. Jednakże, użycie skanowania PET/ CT skutkuje najczęściej stwierdzeniem większej liczby przerzutów do węzłów chłonnych w stosunku do wyników badania ce , co nie wyklucza możliwość podjęcia terapii agresywnej, a jedynie zmniejsza prawdopodobieństwo pełnego wyleczenia choroby. Według autorów [4,16,17], opisywane powyżej zjawisko jest szczególnie dostrzegalne w grupie chorych ze stwierdzonym OSCC i OAC, których poddano badaniu ${ }^{18}$ F-FDG PET/CT. Zgodnie z literaturą [15-17], wdrożenie techniki PET/CT w postępowanie diagnostyczne wobec chorych z OC, może skutkować zmianą oceny TNM nawet w połowie badanych przypadków, zmieniając podejście terapeutyczne u około $20 \%$.

\section{Dyskusja}

Z uwagi na mnogość wariantów terapeutycznych, stosowanych w przypadku OSCC i OAC, postępowanie diagnostyczne wobec chorych onkologicznie z rozpoznanym OC, wymaga kompleksowej diagnostyki, obejmującej użycie zaawansowanych metod obrazowania. Badaniem z wyboru w ewaluacji ogniska pierwotnego jest EUS. W pozostałych przypadkach, powszechnie stosowanymi technikami są ce $\mathrm{CT} \mathrm{i}^{18} \mathrm{~F}-\mathrm{FDG}$ PET/CT. Badanie e CT stanowi nieodłączny element procesu planowania teleradioterapii, ponieważ tomogramy CT wykorzystywane są do określania pola napromieniania, uwzględniającego także ochronę narządów krytycznych. Skanowanie ${ }^{18} \mathrm{~F}-\mathrm{FDG}$ PET/CT, mimo ograniczonej rozdzielczości przestrzennej, pozwala wskazać obszary wzmożonej aktywności metabolizmu glukozy, co pozwala precyzyjnie określić obszar, który powinien zostać objęty leczeniem (zarówno w trakcie leczenia choroby pierwotnej, jak i wznowy nowotworowej).

Zgodnie z zaleceniami, z ang. National Comprehensive Cancer Network (NCCN), European Society for Medical Oncology (ESMO), a także Polskiej Unii Onkologii (PUO), metodą z wyboru w leczeniu OC w stopniu zaawansowania miejscowo-regionalnym, jest radiochemioterapia przedoperacyjna, skojarzona z chirurgią (schemat leczenia radykalnego). Warunkiem kwalifikacji do leczenia jest jednakże wykluczenie obecności przerzutów odległych (cecha M) i precyzyjne określenie stopnia zaawansowania węzłowego. Czułość i swoistość metody ${ }^{18} \mathrm{~F}-\mathrm{FDG}$ PET/CT w ocenie stopnia zaawansowania OC w skali TNM sięga odpowiednio 81\% i 91\% (cecha M), co czyni technikę potencjalnie najbardziej użytecznym narzędziem diagnostycznym, służącym kwalifikacji do leczenia radykalnego zarówno OSCC, jak i OAC.

Z uwagi na ograniczoną dostępność techniki ${ }^{18}$ F-FDG PET/CT (niewielka liczba aparatów PET) i wyższe -

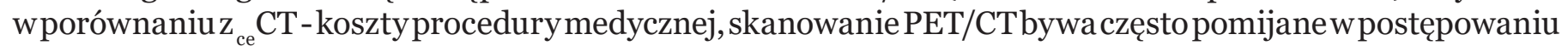
diagnostycznym wobec chorych z rozpoznanym OC. Zgodnie z literaturą $[4,16,17]$, użycie metody ${ }^{18} \mathrm{~F}-\mathrm{FDG}$ PET/CT pozwala na wykrycie większości istniejących ognisk nowotworowych, towarzyszących rozwojowi OC. Jako takie, zdaniem autorów, badanie ${ }^{18}$ F-FDG PET/CT powinno być stosowane szczególnie na etapie planowania i ewaluacji skuteczności terapii, jak również oceny wznowy nowotworowej.

\section{Wnioski}

Mimo ograniczeń, metoda ${ }^{18} \mathrm{~F}-\mathrm{FDG}$ PET/CT uznawana jest za najbardziej użyteczną w ocenie stopnia zaawansowania i planowaniu leczenia wszystkich podtypów histologicznych nowotworu złośliwego przełyku.

\section{Konflikt interesu / Conflict of interest}

Nie występuje / None

\section{Etyka / Ethics}

Treści przedstawione w artykule są zgodne z zasadami Deklaracji Helsińskiej, dyrektywami EU oraz ujednoliconymi wymaganiami dla czasopism biomedycznych. 


\section{Piśmiennictwo / References}

[1] Smyth EC, Lagergren J, Fitzgerald RC, Lordick F, Shah MA, et al. Oesophageal Cancer. Nat Rev Dis Primers. 2017;3:17048.

[2] Foley K, Findlay J, Goh V. Novel imaging techniques in staging oesophageal cancer. Best Pract Res Clin Gastroenterol. 2018;36-37:17-25.

[3] Wang WP, Ni PZ, Yang YS, He SL, Hu WP, et al. The Role and Prognostic Significance of Aortopulmonary, Anterior Mediastinal, and Tracheobronchial Lymph Nodes in Oesophageal Cancer: Update of the EighthEdition TNM Staging System (2018). Ann Surg Oncol. 2019;26:1005-11.

[4] Fatima N, Zaman MU, Zaman A, Zaman U, Tasheen R, et al. Staging and Response Evaluation to NeoAdjuvant Chemoradiation in Esophageal Cancers Using ${ }^{18}$ FDG PET/CT with Standardized Protocol. Asian Pac J Cancer Prev. 2019; 20: 2003-8.

[5] Ogino I, Watanabe S, Hirasawa K, Misumi T, Hata M, et al. The Importance of Concurrent Chemotherapy for T1 Esophageal Cancer: Role of FDG-PET/CT for Local Control. In vivo. 2018; 32: 1269-74.

[6] Tsuchitani T, Takahashi Y, Maeda Y, Oda M, Enoki T, et al. Investigation of appropriate semi-quantitative index for assessment of esophageal and breast cancer treatment response in Japanese patients using ${ }^{18}$ F-FDG PET/CT findings. Hell J Nucl Med. 2019; 22: 20-4.

[7] Martenka P. Ocena najnowszych trendów w diagnozowaniu i leczeniu nowotworów złośliwych górnego odcinka układu pokarmowego na rok 2014 wg doniesień prezentowanych podczas konferencji ASTRO 56 w San Francisco. Letters in Oncology Science 2017;14:80-5.

[8] Cuellar SLB, Palacio DP, Beneveniste MF, Carter BW, Hofstetter WL, et al. Positron Emission Tomography/Computed Tomography in Esophageal Carcinoma: Applications and Limitations. Semin Ultrasound CT MRI. 2017;38:571-83.

[9] Jeong DY, Kim MY, Lee KS, Choi JY, Kim SJ, et al. Surgically resected T1-and T2-stage esophageal squamous cell carcinoma: T and N staging performance of EUS and PET/CT. Cancer Med. 2018;00:1-10.

[10] Offman J, Pesola F, Sasieni P. Trends and projections in adenocarcinoma and squamous cell carcinoma of the oesophagus in England from 1971 to 2037. Br J Cancer. 2018;118:1391-8.

[11] Old OJ, Isabelle M, Barr H. Chapter 9. Staging Early Esophageal Cancer. Rozdz w: Jansen M, Wright NA. Stem Cells, Pre-neoplasia and Early Cancer of the Upper Gastrointestinal Tract, Advances in Experimental Medicine and Biology 908. Springer International Publishing Switzerland 2016;161-81.

[12] Goel R, Subramaniam RM, Wachsmann JW. PET/Computed Tomography Scanning and Precision Medicine. Esophageal Cancer. PET Clin. 2017: 11-12.

[13] Dong Y, Wei Y, Chen G, Huang Y, Song P, et al. Relationship Between Clinicopathological Characteristics and PET/CT Uptake in Esophageal Squamous Cell Carcinoma: [ $\left.{ }^{18} \mathrm{~F}\right]$ Alfatide versus $\left[{ }^{18} \mathrm{~F}\right] \mathrm{FDG}$. Mol Imaging Biol. 2019;21:175-81.

[14] Dellaportas D, Zylstra J, Gossage J, Baker C, Kelly M, et al. The Prognostic Role of Pre-operative Positron Emission Tomography-Computed Tomography and Endoscopic Ultrasound Parameters in Oesophageal Adenocarcinoma. Chirurgia. 2019;114: 443-50.

[15] Pietrzak AK, Martenka P, Strzesak E, Wierzchosławska E, Marszałek A, et al. Will Rogers phenomenon in the oesophageal cancer patients staging - CT versus ${ }^{18} \mathrm{~F}-\mathrm{FDG}$ PET/CT: retrospective study. Hell $\mathrm{J}$ Nucl Med. 2019;22(Supp 2):174-80.

[16] Walker MJ, Rogers W. Defining disease in the context of overdiagnosis. Med Health Care Philos. 2017;20:269-80.

[17] Lee NCJ, Eskander A, Park HS, Mehra S, Burtness MA, et al. Pathologic staging changes in oral cavity squamous cell carcinoma: Stage migration and implications for adjuvant treatment. Cancer. 2019:125:2975-8. 